Editorial Invitado / Guest Editorial

\title{
Integración de las TIC a la educación: Una mirada desde el aula universitaria
}

\author{
Integration of ICTs to education: A look from the university classroom \\ Ronald M. Hernández \\ https://orcid.org/0000-0003-1263-2454 \\ Universidad San Ignacio de Loyola, Perú \\ Antonio Rodríguez-Fuentes \\ https://orcid.org/0000-0002-8036-9902 \\ Universidad de Granada, España \\ Néstor Roselli \\ https://orcid.org/0000-0002-7313-4566 \\ Pontificia Universidad Católica Argentina, Argentina
}

\section{Cita RecomendadA}

Hernández, R., Rodriguez-Fuentes, A. \& Roselli, N., (2019).Integración de las TIC a la educación: Una mirada desde el aula universitaria. Hamut'ay, 6(3), 9-11.

http://dx.doi.org/10.21503/hamu.v6i3.1839

\section{INTEGRACIÓN DE LAS TIC A LA EDUCACIÓN: UNA MIRADA DESDE EL AULA UNIVERSITARIA}

El uso de las tecnologías de la información y comunicación (TIC) son un elemento clave en los procesos de interacción de los seres humanos (Coll, 2004) y su impacto en la sociedad ha traído grandes cambios, respecto a forma y contenido (Hernández, 2017). Para Parra (2012) uno de los lugares donde la tecnología ha influenciado mayoritariamente es en la educación, llegando a formar parte de la cotidianidad escolar y la relación entre docentes y estudiantes, además de convertirse en una pieza clave para los avances y cambios en el ámbito educativo, en especial en la educación superior. Por ello, las instituciones de educación superior presentan nuevos retos y en respuesta a ello es el desafío que han asumido las universidades para romper las barreras de exclusividad y avanzar hacia una educación inclusiva, que atienda los distintos estilos de enseñanza-aprendizaje, a la diversidad de estudiantes

\section{INTEGRATION OF ICTS TO EDUCATION: A} LOOK FROM THE UNIVERSITY CLASSROOM

Information and communication technologies (ICTs) are a key element in the processes of interaction of human beings (Coll, 2004) and their impact on society has brought great changes, regarding form and content (Hernández, 2017). For Parra (2012), one of the places where technology has greatly influenced is education at all levels, becoming part of the school's daily life and the relationship between teachers and students, becoming a key piece for the progress and changes in the educational field, especially for higher education. The use of social networks in the exchange of information and in the generation of content in different scenarios of society is massive. Therefore, higher education institutions face new challenges and in response to this, it's the challenge that universities have assumed to break the barriers of exclusivity and move towards an inclusive education that addresses the different 
que asisten a sus centros. Se está formando una nueva era de recursos tecnológicos usados para el aprendizaje, lo que lleva a toda comunidad educativa a un proceso de adaptación, de esta manera se pasa de una sociedad denominada estática, a una sociedad de nativos digitales (Graells, 2013; Agudo, Alvarez-Arregui, Rodríguez-Martín, \& Rosal, 2017).

Un enfoque holístico de las TIC ha permitido integrar el currículo educativo a una serie de herramientas que conforman nuevas metodologías, didáctica e instrumentos de enseñanza-aprendizaje.

Las TIC se han convertido en un recurso necesario que permite la transmisión de nuevos conocimientos, actitudes y valores, permitiendo un fácil acceso a las fuentes de información, permitiendo el desarrollo de habilidades para articular conocimientos a través de las nuevas herramientas (Novillo, Espinoza, \& Ramiro, 2017). Para Díaz-Barriga, (2013) la incorporación de las TIC, a la educación, se ha convertido en un proceso cuya implicancia, va mucho más allá de las herramientas tecnológicas que conforman el ambiente educativo, se habla de una construcción didáctica y la manera cómo se pueda construir y consolidar un aprendizaje significativo en base a la tecnología, en estricto pedagógico se habla del uso tecnológico a la educación. Aunado a ello las bondades que brinda el Internet como un medio para lograr que las sociedades estén conectadas a nivel mundial y que la nueva información se puede revisar fácilmente dentro y fuera de las aulas; sin embargo, no solo requiere de una implementación educativa, es importante que la comunidad educativa tenga dentro de sus planes de competencia, el conocimiento el manejo de las herramientas tecnológicas dentro de las aulas (Navarrete, \& Mendieta, 2018). Para López (2014, p. 25) plantea que la incorporación de las TIC en el ámbito educativo, es una necesidad que requiere ser atendida con carácter de urgencia y obligatoriedad, no solo dentro del marco educacional, sino desde la perspectiva de capacitación y actualización, ampliación y profundización del conocimiento. Pero su asociación a la educación también debe tratarse con conciencia, reconociendo que el acceso a las TIC es solo un medio hacia la calidad educativa, ya que existen herramientas y recursos que per- teaching and learning styles. These environments assisted by electronic elements such as augmented reality, artificial intelligence, data mining, virtual worlds, metaverses, among others have formed a new era of technological resources used for learning, which leads every educational community to an adaptation process; in this way, we move from a society called static, to a society of digital natives (Graells, 2013; Agudo, Álvarez-Arregui, Rodríguez-Martín, \& Rosal, 2017).

A holistic approach to ICTs has allowed the integration of the educational curriculum into a series of tools that make up new methodologies, instruction and teaching and learning tools. ICTs have become a necessary resource that allow the transmission of new knowledge, attitudes and values, making it possible the development of skills to articulate knowledge through the new tools (Novillo, Espinoza, \& Ramiro, 2017). For Díaz-Barriga, (2013) the incorporation of ICTs into education, has become a process whose implication goes far beyond the technological tools that make up the educational environment; it's being discussed the need of a didactic construction and the way how significant learning can be built and consolidated based on technology ; pedagogically speaking, it's about the technological use for education. In addition, we have the benefits offered by the Internet as a means to ensure that societies are connected worldwide and that new information can be easily reviewed inside and outside the classroom; However, it does not only require an educational implementation, it is important that the educational community has within its competence plans, the knowledge of the management of technological tools within the classroom (Navarrete, \& Mendieta, 2018). López (2014, p. 25) states that the incorporation of ICTs in the educational field is a necessity that needs to be addressed as a matter of urgency and obligation, not only within the educational framework, but also from the perspective of training and updating, expansion and deepening of knowledge. Its association with education must also be treated with awareness, recognizing that the access to ICTs is only a means towards educational quality, since there are tools and resources that allow an educational update through the network. The important thing about it, is how 
miten una actualización educativa a través de la red. Lo importante de ello, es como estas tecnologías son incorporadas en los procesos educativos de calidad, hecho que recae no solo en centrarse en aspectos instrumentales tecnológicos, pues es necesario involucrar las competencias y disminuir las brechas digitales de formación, forjando una sociedad que genere nuevas formas de ver el mundo a través de la ciencia, la innovación y la tecnología y dentro del actual los docentes tienen un rol importante, al tener que apropiarse, aplicar y ejecutar estos recursos tecnológicos en sus procesos de enseñanza aprendizaje.

\section{ReFERENCIAS Bibliográficas / Bibliographic Referencies}

Agudo, S., Alvarez-Arregui, E., Rodríguez-Martín, A., \& Rosal, I. (2017). Innovando en el aula universitaria con TIC. En Ruiz-Palmero, J., Sánchez-Rodríguez, J. y Sánchez-Rivas, E. (Edit.). Innovación docente y uso de las TIC en educación. Málaga: UMA Editorial.

Coll, C. (2004). Psicología de la educación y prácticas educativas mediadas por las tecnologías de la información y la comunicación. Una mirada constructivista. Revista Electrónica Sinéctica, (25), 1-24.

Graells, P. (2013). Impacto de las TIC en la educación: funciones y limitaciones. 3 c TIC: cuadernos de desarrollo aplicados a las TIC, 2(1), 1-15.

Hernández, R. (2017). Impacto de las TIC en la educación: Retos y Perspectivas. Propósitos y Representaciones, 5(1), 325-347. https://doi.org/10.20511/pyr2017.v5n1.149

López, (2014). Uso de las tecnologías de la información y la comunicación en la administración curricular de postgrado. Investigación y Postgrado, 29(1), 183-212.

Navarrete, G., \& Mendieta, R., (2018). Las TIC y la educación ecuatoriana en tiempos de internet: breve análisis. Espirales Revista Multidisciplinaria de investigación, 2(15).

Novillo, E., Espinoza, M., \& Ramiro, J., (2017). Influencia de las TIC en la educación universitaria, caso Universidad Técnica de Machala. INNOVA Research Journal, 2(3), 6979. https://doi.org/10.33890/innova.v2.n3.2017.136

Parra, C. (2012). TIC, conocimiento, educación y competencias tecnológicas en la formación de maestros. Nómadas, $36,145-159$. these technologies are incorporated into quality educational processes, a fact that lies not only in focusing on technological instrumental aspects, since this multidimensional reality contemplates ontological and axiological aspects that must be explained as well as phenomenologically clarified to understand the different socio-cultural realities, building up a society that generates new ways of seeing the world through science, innovation and technology. 